\title{
Correlation and path analysis for agro-morphological traits in rajmash beans under Baramulla- Kashmir region
}

\author{
Shahid Ahmed ${ }^{1}$ and Kamaluddin ${ }^{2 *}$ \\ ${ }^{1}$ Crop Improvement Division, IGFRI, Jhansi, India. \\ ${ }^{2}$ Faculty of Agriculture, SKUAST-Kashmir, Wadura Campus, Sopore, J and K, India.
}

Accepted 09 May, 2013

\begin{abstract}
Correlation and path analysis were studied in $\mathbf{5 7}$ germplasm lines of rajmash beans for yield and yield contributing traits. Significant variations were observed for plant height, number of pods/plant, 100 seed weight and seed yield. Low level of difference between the magnitude of phenotypic coefficient of variation (PCV) and genetic coefficient of variation (GCV) for days to $50 \%$ flowering, plant height, 100 seed weight and seed yield indicated that the traits were least influenced by environment and are genetically controlled. High heritability and high genetic advance was observed for plant height, 100 seed weight and days to $50 \%$ flowering. Seed yield was found to be positively correlated with days to $50 \%$ flowering, plant height, pod length, number of pods/plant and number of seeds/pod. Path coefficient analysis revealed was $50 \%$ flowering, number of pods/plant, pod length and 100 seed weight showed positive direct effects on seed yield.
\end{abstract}

Key words: Phaseolus vulgaris L., correlation, path analysis, seed yield, diversity, cluster.

\section{INTRODUCTION}

Dry edible beans or field beans haricot with a wide variety of market classes, including kidney bean, navy bean, pinto bean, black bean and snap bean were studied (Harmankaya et al., 2008; Krasu and OZ, 2011). These beans differ in the shape, size, pigmentation and seed color. The rajmash bean (Phaseolus vulgaris L.) is the most important and widely cultivated among others. It is also known as "grain of hope" being an important component of subsistence agriculture and provide food to about 300 million people in tropics and 100 million people in Africa alone (Sofi et al., 2011). In Central America beans are top income generator among field crops. Globally, with 21 million tones, it accounts for about half of the total pulse production (Miklas et al., 2006). This crop plays a significant role in human nutrition, improves soil fertility and is well suited in crop rotation because of its short growing period (Mishra et al., 2010;
Mageshwaran et al., 2012). In India the fresh pods for vegetable use are known as Faras bean or French bean and is also extensively grown as green pod vegetable (Paudel et al., 2003). Whereas dry pods for pulse are known as Rajmash beans. Dry and wet temperate Himalayan region is rich in variability of Faras or French beans which is an important pulse crop of these zones (Rai et al., 2010). In North Himalaya region of India, it is grown in kharif season (crop grown in summer season in India, that is, from onset of monsoon, June-July to September-October) as mixtures with other landraces or with other crops. Different factors like biotic and abiotic stresses, differences in flowering and maturity duration and shattering are responsible for reduction in its production. Besides lack of uniformity in size of seeds and color, crop also fetches poor market price. Therefore, it becomes important to have a systematic breeding plan 
for genetic improvement of this important pulse crop as this will help in improvement of health and wealth of poor farmers living in harder regions of India.

Seed yield is a complex dependent character and is contributed by several component characters. Direct selection for seed yield is often not very effective and thus indirect selection for some of the associated component traits may be useful. Genotypic and phenotypic correlations of yield components, path analysis and diversity become useful for crop improvement programmes to select the desirable types. However, meager information is available on these aspects in this crop for the defined region. Rai et al. (2006) reported highest genetic coefficient of variation (GCV) and phenotypic coefficient of variation (PCV) for days to initiation of flowering, days to $50 \%$ flowering, plant height, primary branches/plant and clusters/plant. High heritability with high genetic advance was reported for yield/plant, pod length and pods/plant (Singh et al., 2007). Sofi et al. (2011) observed that seed yield was significantly associated with number of pods/plant followed by 100 seed weight, seeds/pod and plant height. Number of pods/plant, percent of fruit set/cluster and number of seeds/pod showed maximum direct effect on yield (Rai et al., 2010). Krasu and OZ (2011) concluded that the seed yield/plant had the highest direct effect on 1000 seed weight and plant height.

Keeping in view, a study was conducted to evaluate the performance and association among yield contributing traits of indigenous and exotic material of Rajmash bean under temperate conditions.

\section{MATERIALS AND METHODS}

\section{Plant sample and experimental design}

Fifty seven germplasm lines of Rajmash bean were evaluated in Randomized Block Design with three replications during Kharif 2006 and 2007 at Plant Breeding and Genetics Farm of Regional Research Station, SKUAST-K, Wadura, Sopore, Kashmir. These germplasm comprised of the locally collected accessions from different parts of the Kashmir Valley and exotic and indigenous germplasm lines. Exotic accessions were consisted of 17 genotypes namely EC-285559, EC-285566, EC-285578, EC285572, EC-285565, EC-285551, EC-285569, EC-285558, EC285579, EC-285553, EC-285550, EC-285582, EC-285573, EC285580, EC-285549, Exotic Pink I and Exotic Pink-II and procured from Bolivia. Each accession was grown in a row of $5 \mathrm{~m}$ length apart, $30 \mathrm{~cm}$ line-line and plant to plant spacing of $10 \mathrm{~cm}$ in three replications. Agronomic practices recommended for normal fertility were followed and the soil was fertilized with $30 \mathrm{~kg}$ of N/ha, $60 \mathrm{~kg}$ of $\mathrm{P}_{2} \mathrm{O}_{5} / \mathrm{ha}$ and $30 \mathrm{~kg}$ of $\mathrm{K}_{2} \mathrm{O} / \mathrm{ha}$ at sowing. Iron poles were used to support the twigs of tall plants. The data were recorded on 10 randomly selected plants from each accession in each replication for various quantitative traits; days to $50 \%$ flowering (in days), plant height $(\mathrm{cm})$, number of pods/plant, pod length $(\mathrm{cm})$, number of seeds/pod, 100 seed weight $(\mathrm{g})$ and seed yield $(\mathrm{kg} / \mathrm{h})$.

\section{Data analysis}

Analysis of variance was carried out as per standard procedure described by Panse and Sukhatme (1985), GCV and PCV were calculated following the formula given by Burton and deVane (1953). Heritability $\left(\mathrm{h}^{2}\right)$ and genetic advance (GA) was estimated as per the Johnson et al. (1955) and correlation coefficients by Singh and Chaudhary (1979). Path coefficients analysis was carried out according to Dewey and Lu (1959).

\section{RESULTS AND DISCUSSION}

The analysis of variance revealed significant variability for all the traits studied. Plant height exhibited high variability; whereas days to $50 \%$ flowering, 100 seed weight and seed yield ( $\mathrm{kg} / \mathrm{ha})$ showed moderate and number of pods/plant, pod length and number of seeds/pod showed low variability. Mean values, coefficient of variation (CV), GCV, PCV, $\mathrm{h}^{2}$ and GA for yield and other yield contributing characters are presented in Table 1. Maximum CV (22.66\%) was observed for seed yield followed by number of pods/plant $(15.26 \%)$ and number of seeds/pod (13.93\%). The plant height showed maximum variability (46.33 to 132.67 ) but it has low CV (5.97\%). The extent of variation expressed by different traits can be properly judged through estimates of PCV and GCV. The deviation of GCV from PCV (Table 1) in case of days to $50 \%$ flowering, plant height, seed yield and 100 seed weight was observed to be low and a major portion of PCV may be due to genetic causes, whereas, number of seeds/pod, number of pods/plant and pod length showed moderate variation. Nehvi et al. (2007) reported sufficient genetic variability for different quantitative traits in beans.

Partitioning of total phenotypic variance into heritable and non-heritable components revealed high heritability estimates for plant height, 100 seed weight, number of pods/plant, seed yield and days to $50 \%$ flowering, thereby suggesting the usefulness of making selection based on phenotypic observations. This high heritability may be due to additive gene effects hence these traits are likely to respond to direct selection. Since broad sense heritability represents the upper limit that can be achieved through selection, such estimates should be used judiciously for evaluation studies. Moderate heritability estimates were observed for pod length. Heritability in conjunction with genetic advance is more useful than heritability alone in predicting the resultant effect for selecting the best genotype for a given trait. High heritability estimates coupled with high genetic advance (Table 1) was observed for plant height, 100 seed weight and days to $50 \%$ flowering. This suggested that genotypic variation for these traits may be possibly due to high additive gene effects and direct selection for such traits would prove effective. Kamaluddin and Ahmad (2011) also observed high heritability along with high genetic advance for plant height, 100 seed weight and days to $50 \%$ flowering. Similarly, High heritability coupled with high genetic advance for 100 seed weight was also reported by Rai et al. (2010). Rest of the traits namely seed yield, number of pods/plant, pod length and number 
Table 1. Variability parameters for seed yield and yield related traits

\begin{tabular}{|c|c|c|c|c|c|c|c|}
\hline Traits/parameter & $\begin{array}{c}\text { Days to } 50 \% \\
\text { flowering }\end{array}$ & $\begin{array}{l}\text { Plant height } \\
\text { (cm) }\end{array}$ & $\begin{array}{c}\text { No. of } \\
\text { pods/plant }\end{array}$ & $\begin{array}{l}\text { Pod length } \\
\text { (cm) }\end{array}$ & $\begin{array}{c}\text { No. of } \\
\text { seeds/pod }\end{array}$ & $\begin{array}{c}100 \text { seed weight } \\
(\mathrm{g})\end{array}$ & $\begin{array}{c}\text { Seed yield } \\
(\mathrm{kg} / \mathrm{ha})\end{array}$ \\
\hline Mean & 67.18 & 89.50 & 5.50 & 10.65 & 4.63 & 36.33 & 526 \\
\hline Range & $58-78$ & 46.33-132.67 & 3-10 & $7-13$ & $4-6$ & $25-45$ & $180-1290$ \\
\hline PCV (\%) & 5.45 & 32.85 & 24.45 & 10.04 & 13.33 & 15.68 & 41.52 \\
\hline GCV (\%) & 5.10 & 32.59 & 23.37 & 8.65 & 9.99 & 15.31 & 41.44 \\
\hline C.V (\%) & 1.92 & 5.97 & 15.26 & 5.09 & 13.93 & 3.39 & 22.66 \\
\hline C.D (5\%) & 2.09 & 2.53 & 0.63 & 0.87 & 0.63 & 1.99 & 0.22 \\
\hline h2 (\%) & 87.50 & 98.40 & 91.40 & 74.20 & 58.0 & 95.30 & 90.60 \\
\hline GA & 6.60 & 25.28 & 2.53 & 1.63 & 0.72 & 11.19 & 4.48 \\
\hline GA as $\%$ of mean & 9.83 & 82.72 & 46.03 & 15.35 & 1.62 & 30.79 & 85.21 \\
\hline
\end{tabular}

of seeds /pod showed low genetic advance besides moderate heritability so in case of such traits, non-additive gene effects appears to be of considerable importance. The importance of genetic advance lies in providing an idea about the amount of progress that can be achieved by selecting the concerned trait. The expected genetic advance as percent of means varied from $1.62 \%$ for number of seeds/pod to $82.72 \%$ for plant height (Table 1). From the discussion this is evident that, a direct selection among germplasm accessions may bring about significant improvement in yield and its component traits.

Correlation studies indicated that days to $50 \%$ flowering is positively correlated with plant height (0.902), number of seeds/pod (0.568) and seed yield $(0.658)$ while it showed negative correlation with pod length (-0.712) and 100 seed weight (0.801 ). Plant height is positively correlated with seed yield, number of pods /plant and number of seeds /pod and showed negative correlation with pod length and 100 seed weight (Table 2). The number of pods/plant showed strong positive correlation with number of seeds/pod and seed yield and negatively correlated with pod length and 100 seed weight. Similarly the pod length is positively correlated with 100 seed weight, number of seeds/pod and seed yield whereas the number of seeds/pod is positively correlated with seed yield and it showed negative correlation with 100 seed weight. The seed yield showed strong direct correlation with number of days to $50 \%$ flowering followed by number of pods/plant, pod length and number of seeds/pod. It showed negative correlation with 100 seed weight. Results are in conformity with the findings of Bhushan et al. (2008), Kumar et al. (2009) and Sofi et al. (2011).

Path coefficient analysis was used to partition the correlation coefficient into direct and indirect effects of different traits. Path analysis revealed that days to $50 \%$ flowering had maximum positive direct effect on seed yield followed by number of pods/plant, pods length and number of seeds/pod indicating true and perfect relationship among these traits (Table 3 ). The highest positive correlation between days to $50 \%$ flowering and seed yield was obtained largely by its direct effect (Figure 1).

Plant height and number of seeds/pod had negative direct effect on seed yield. The positive correlation between plant height and seed yield was obtained mainly through indirect effect through days to $50 \%$ flowering and number of pods/plant. The positive correlation of seed yield with number of seeds/pod was obtained largely through indirect effect of number of pods/plant and days to $50 \%$ flowering. Earlier, positive direct effect on seed yield has been reported by Rai et al. (2006) for pod weight and number of seeds/pod; maximum direct effect was found in number of pods/plant followed by number of seeds/pod towards yield (Figure 2), (Rai et al., 2010). Therefore, most of these studies support the present findings. The traits with higher genetic variability, heritability, higher expected genetic gain under selection and are significantly correlated with seed yield can be reliably used to improve seed yield through indirect selection.

\section{Conclusion}

In the present study, number of seeds/pod, days to $50 \%$ flowering, plant height and number of pods/plant showed positive and significant association with yield. Days to $50 \%$ flowering, number of pods/plant, 100 seed weight and pod 
Table 2. Genotypic and phenotypic correlation matrix for yield and related traits in Rajmash bean.

\begin{tabular}{|c|c|c|c|c|c|c|c|}
\hline Character & Days to $50 \%$ flowering & Plant height & No. of pods/plant & Pod length & No. of seeds/pod & 100 seed weight & Yield (kg/ha) \\
\hline \multirow{2}{*}{ Days to $50 \%$ flowering } & 1.00 & $\left(0.905^{\star \star}\right)$ & $\left(-0.266^{\star \star}\right)$ & $\left(-0.733^{\star \star}\right)$ & $(0.569)$ & $\left(-0.823^{\star \star}\right)$ & $\left(0.659^{\star \star}\right)$ \\
\hline & & $0.902^{\star *}$ & $-0.254^{* *}$ & $-0.712^{\star *}$ & $0.568^{\star *}$ & $-0.801^{\star *}$ & $0.658^{* *}$ \\
\hline \multirow{2}{*}{ Plant height (cm) } & & 1.00 & $\left(0.190^{\star \star}\right)$ & $(-0.120)$ & $(0.036)$ & $\left(-0.357^{\star \star}\right)$ & $(0.048)$ \\
\hline & & & $0.177^{*}$ & -0.100 & 0.027 & $-0.349^{\star \star}$ & 0.046 \\
\hline \multirow{2}{*}{ No. of pods/plant } & & & 1.00 & $\left(-0.202^{\star \star}\right)$ & $\left(0.204^{\star \star}\right)$ & $\left(-0.351^{* \star}\right)$ & $\left(0.171^{\star}\right)$ \\
\hline & & & & $-0.162^{*}$ & $0.171^{*}$ & $-0.342^{\star *}$ & $0.163^{*}$ \\
\hline \multirow{2}{*}{ Pod length } & & & & 1.00 & $(0.053)$ & $(0.095)$ & $(0.139)$ \\
\hline & & & & & 0.038 & 0.075 & 0.118 \\
\hline \multirow{2}{*}{ No. of seeds/pod } & & & & & 1.00 & $(-0.104)$ & $(0.097)$ \\
\hline & & & & & & -0.096 & 0.079 \\
\hline \multirow{2}{*}{100 seed weight } & & & & & & 1.00 & -0.131 \\
\hline & & & & & & & -0.129 \\
\hline
\end{tabular}

* ${ }^{* *}$ Significant at the 0.05 and 0.01 probability levels, respectively; Values in parentheses are genotypic correlation.

Table 3. Estimates of direct and indirect effects on seed yield and related traits.

\begin{tabular}{|c|c|c|c|c|c|c|c|c|}
\hline Trait & & $\begin{array}{l}\text { Days to } 50 \% \\
\text { flowering }\end{array}$ & $\begin{array}{c}\text { Plant } \\
\text { height }\end{array}$ & $\begin{array}{c}\text { No. of } \\
\text { pods/plant }\end{array}$ & $\begin{array}{l}\text { Pod } \\
\text { length }\end{array}$ & $\begin{array}{c}\text { No. of } \\
\text { seeds/pod }\end{array}$ & $\begin{array}{c}100 \text { seed } \\
\text { weight }\end{array}$ & $\begin{array}{c}\text { Correlation with seed } \\
\text { yield }\end{array}$ \\
\hline \multirow{2}{*}{ Days to $50 \%$ flowering } & $\mathrm{G}$ & 0.019 & -0.001 & -0.005 & -0.001 & -0.002 & 0.005 & $0.659^{\star \star}$ \\
\hline & $P$ & 0.013 & -0.001 & -0.003 & -0.001 & -0.001 & 0.003 & $0.658^{\star *}$ \\
\hline \multirow{2}{*}{ Plant height } & $\mathrm{G}$ & 0.004 & -0.138 & -0.026 & -0.016 & 0.005 & 0.049 & 0.048 \\
\hline & $P$ & 0.003 & -0.127 & -0.022 & -0.012 & 0.003 & 0.044 & 0.046 \\
\hline \multirow{2}{*}{ No. of pods/plant } & $\mathrm{G}$ & -0.028 & 0.020 & 0.108 & 0.021 & 0.022 & -0.038 & $0.171^{*}$ \\
\hline & $P$ & -0.029 & 0.020 & 0.115 & 0.018 & 0.019 & -0.039 & $0.163^{*}$ \\
\hline \multirow{2}{*}{ Pod length } & $\mathrm{G}$ & -0.005 & 0.017 & 0.029 & 0.147 & 0.048 & 0.014 & 0.139 \\
\hline & $\mathrm{P}$ & -0.003 & 0.012 & 0.019 & 0.121 & 0.004 & 0.009 & 0.118 \\
\hline
\end{tabular}


Table 3. Contd.

\begin{tabular}{|c|c|c|c|c|c|c|c|c|}
\hline \multirow{2}{*}{ No. of seeds/pod } & $\mathrm{G}$ & -0.006 & -0.001 & 0.009 & 0.002 & 0.016 & -0.005 & 0.097 \\
\hline & $\mathrm{P}$ & -0.003 & -0.001 & 0.006 & 0.001 & 0.039 & -0.003 & 0.079 \\
\hline \multirow{2}{*}{100 seed weight } & $\mathrm{G}$ & -0.041 & 0.056 & 0.055 & -0.015 & 0.097 & -0.156 & -0.131 \\
\hline & $\mathrm{P}$ & -0.033 & 0.049 & 0.048 & -0.010 & 0.013 & -0.141 & -0.127 \\
\hline
\end{tabular}

$\mathrm{R}$ square $=0.069$; residual effect $=0.964 ;{ }^{*} ;{ }^{* *}$ Significant at the 0.05 and 0.01 probability levels, respectively.

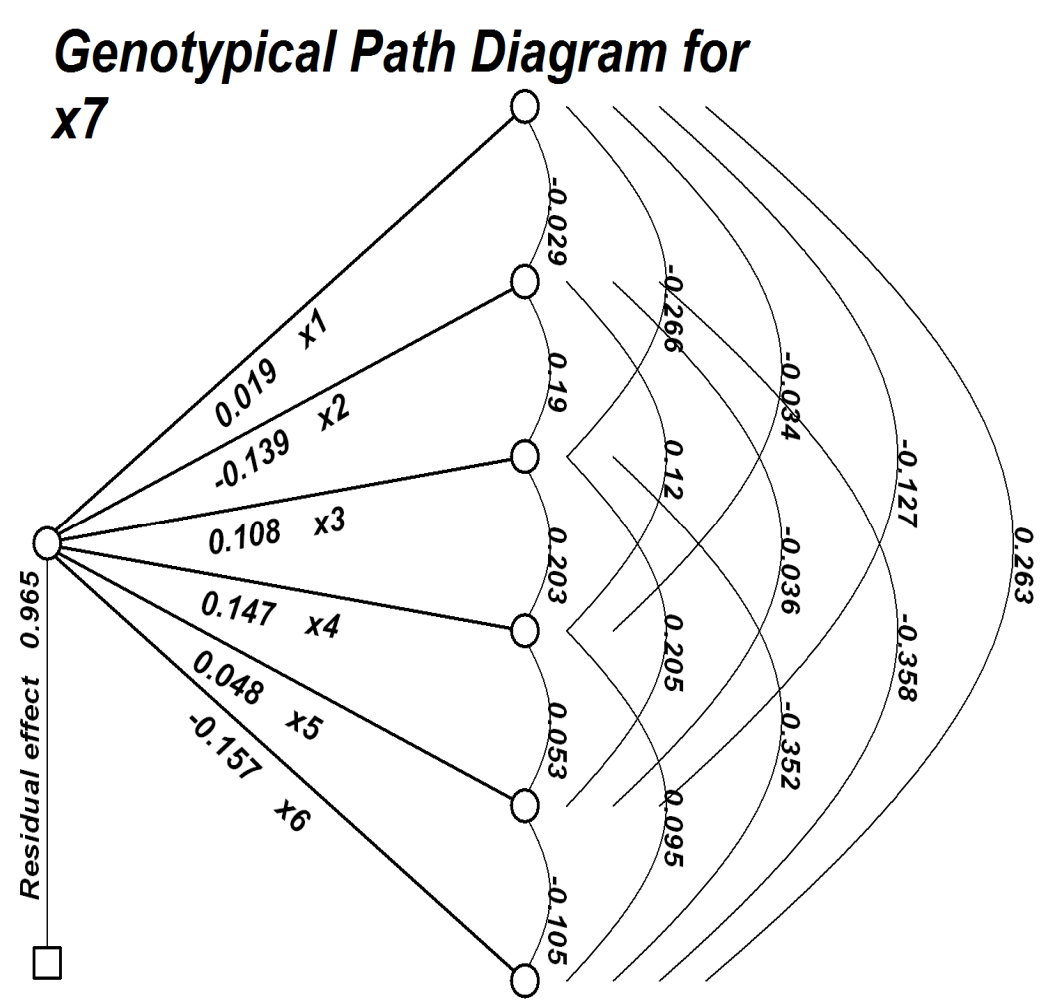

Figure 1. Genotypic path diagram for grain yield and related traits in genotypes used in the study; $X 7=$ Seed yield, $X 1$ = days to $50 \%$ flowering, $\mathrm{X} 2=$ plant height, $\mathrm{X} 3=$ number of pods $/$ plant, $\mathrm{X} 4=$ pod length, $\mathrm{X} 5=$ number of seeds/pod, $X 6=100$ seed weight. 


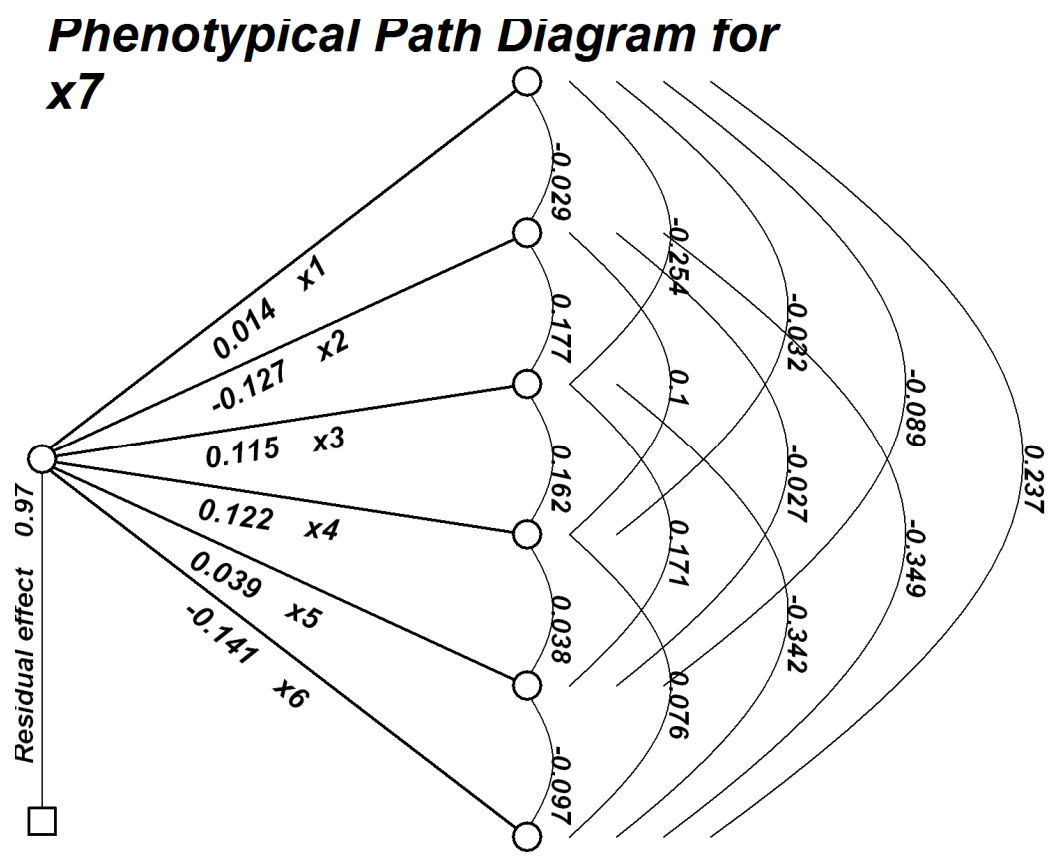

Figure 2. Phenotypic path diagram for grain yield and related traits in genotypes used in the study; $X 7=$ Seed yield, $X 1=$ days to $50 \%$ flowering, $X 2=$ plant height, $\mathrm{X} 3=$ number of pods $/$ plant, $X 4=$ pod length, $X 5=$ number of seeds $/$ pod, $X 6=100$ seed weight.

length had maximum positive direct effect on seed yield. Therefore selection for these traits indirectly affects seed yield.

\section{REFERENCES}

Bhushan KB, Jadli S, Verma O, Goswami AK (2008). Plant characters correlation and path coefficient analysis of seed yield in exotic french bean (Phaseolus vulgaris L.) germplasm. Internat. J. Agric. Sci. 4(2):667-669.

Burton GW, deVane EH (1953). Estimating heritability in tall fescue (Festuca arundinacea) from replicated clonal material. Agron. J. 45 478-481.

Dewey DR, Lu KH (1959). A correlation and path coefficient analysis of components of crested wheat grass seed production. Agron. J. 51:515-518.

Harmankaya M, Onder M, Hamurcu M, Ceyhan M, Gezgin S (2008). Response of common bean (Phaseolus vulgaris L.) cultivars to foliar and soil applied boron in boron deficient calcareous soils. Afr. J. Biotech. 7:3275-3282.

Johnson HW, Robinson HF, Comstock RE (1955). Estimates of genetic and environmental variability in Soybean. Agron. J. 47:314-318.

Kamaluddin, Ahmad S (2011). Variability, correlation and path analysis for seed yield and yield related traits in common beans. Indian $\mathrm{J}$. Hort. 68(1):56-60.

Krasu A, OZ M (2011). A study on coefficient analysis and association between agronomical characters in dry bean (Phaseolus vulgaris L.). Bulgarian J. Agric. Res. 16 (2):203-211.

Kumar A, Singh A, Singh P, Singh SB, Singh V (2009). Relationship and path analysis for green pod yield and its contributing characters over environments in French bean (Phaseolus vulgaris L.). Legume Res. 32(4):270-273.

Mageshwaran V, Mondal KK, Kumar U, Annapurna K (2012). Role of antibiosis on suppression of bacterial common blight disease in
French bean by Paenibacillus polymyxa strain HKA-15. Afr. J. Bio. Tech. 11:12389-12395

Miklas P, Kelly J, Beebi S, Blair M (2006).Common bean breeding for resistance against biotic and abiotic stresses from classical to MAS breeding. Euphytica 147:105-131.

Mishra S, Sharma MK, Singh M, Yadav SK (2010). Genetic diversity of French bean (Bush type) genotypes in North-West Himalayas. Indian J. Plant Genet. Resour. 23(3):285-287.

Nehvi FA, Singh G, Manzar A, Allai BA (2007). Evaluation of local land races of French bean under temperate conditions of kashmir valley. J. Food Legumes 20:41-42.

Panse VG, Sukhatme PV (1985). Statistical methods for agricultural workers. ( $4^{\text {th }}$ edn.). ICAR. New Delhi.

Paudel KB, Chaudhary JN, Gautam IP, Upadhaya KP, Khatri B (2003). Performance of Bush Type French bean in the Hills of Nepal. Proc. of 2nd SAS-N Convention, 30 July - 1 Aug, Kathmandu, Nepal.

Rai N, Asati BS, Singh AK, Yadav DS (2006). Genetic variability, character association and path coefficient study in pole type french bean. Indian J. Hort. 63:188-191.

Rai N, Singh PK, Verma A, Yadav PK, Choubey T (2010). Hierarchical analysis for genetic variability in pole type French bean. Indian $\mathrm{J}$. Hort. 67:150-153.

Singh KP, Minakshi J, Minakshi B (2007). Genetic variability in french bean (Phaseolus vulgaris L.). Res. Crops 8:636-637.

Singh RK, Chaudhary BD (1979). Biometrical methods in quantitative genetic analysis. Kalyani Publishers, New Delhi. P. 288.

Sofi PA, Zargar MY, Debouck D, Graner A (2011). Evaluation of common bean (Phaseolus vulgaris $\mathrm{L}$ ) germplasm under temperate conditions of Kashmir Valley. J. Phytol. 3(8):47-52. 